\title{
Side Friction of Rock-Socketed Piles Involving Thick Sediment
}

\author{
Tie Hang Wang, ${ }^{1}$ Liang Zhang $\mathbb{D},{ }^{1}$ Yan Zhou Hao $\mathbb{D},{ }^{1}$ and Xin Jin ${ }^{2}$ \\ ${ }^{1}$ College of Civil Engineering, Xi'an University of Architecture and Technology, Xi'an, Shaanxi 710055, China \\ ${ }^{2}$ School of Civil \& Architecture Engineering, Xi'an Technological University, Xi'an, Shaanxi 710021, China
}

Correspondence should be addressed to Yan Zhou Hao; 30010508@hncj.edu.cn

Received 1 June 2020; Revised 25 October 2020; Accepted 5 December 2020; Published 16 December 2020

Academic Editor: Xueping Fan

Copyright (c) 2020 Tie Hang Wang et al. This is an open access article distributed under the Creative Commons Attribution License, which permits unrestricted use, distribution, and reproduction in any medium, provided the original work is properly cited.

\begin{abstract}
This paper investigates the skin friction transfer characteristics of the rock-socketed section of a rock-socketed pile resting on thick sediment by conducting in situ core-drilling tests and static loading tests. Test results show that when using the impact holeforming method in weakly cemented soil, a layer of sediment is deposited at the pile bottom. Due to the existence of sediment, when the load reaches a certain value, sudden and large subsidence is observed. This indicates that the end resistance does not contribute to the bearing capacity. Thus, it is not appropriate to consider both end resistance and side resistance in the existing design method of a rock-socketed pile. The bearing capacity of a single rock-socketed pile should be determined according to the side resistance of the soil layer and rock-socketed section only. Numerical analysis is performed to determine the deformation and load-carrying capacity of the pile and the distribution of friction on the sides of the rock-socketed segment. Under a given applied load, small settlement is observed when socketed thickness and rock strength are relatively large. The distribution of side friction of the socketed segment along the vertical direction shows a double-peak saddle shape. When the socketed thickness and rock strength are relatively smaller, the lower peak is higher than the upper peak, and conversely, when the socketed thickness and rock strength are relatively larger, the lower peak is smaller than the upper peak. For a given applied load on the pile top, smaller socketed thickness results in larger settlement and side friction. Due to the thick layer of sediment, the axial force of the rocksocketed segment of the pile gradually decreases along the vertical direction from the applied load on the pile top to zero at the bottom. According to the mechanical properties at different shear stages, a function is derived for the complete constitutive model for a pile-rock interface. Analytical solutions for the friction of a single pile are obtained under the conditions of failure and elasticity deformation of the surrounding rock. Its load transfer equation is derived as well. Accordingly, an equation is proposed for calculating the bearing capacity of rock-socketed piles resting on sediment at the bottom.
\end{abstract}

\section{Introduction}

Rock-socketed pile is a special type of pile foundation that is widely used in the construction of multistoried buildings and bridges. As an important type of bored pile, it is becoming popular in engineering construction in recent years. At present, most rock-socketed piles are constructed by the method of manual excavation or impact drilling. The bottom of manual excavation is clean and easy to check, and the prediction of bearing capacity is reliable, so the manual holeforming method is the most widely used method in engineering construction. However, it is generally applicable only to large-diameter piles, shallow burial depths in bedrock, and shallow groundwater level. Impact hole forming is used where these conditions are not satisfied.

For using the impact hole-forming method, due to the limitations of mechanical equipment and the process of placing steel reinforcement cage and pouring pipe, the upper soil layer (especially the gravel stratum) is collapsed, and a thick layer of loose sediment will be generated at the bottom of the pile. A rock-socketed pile is designed by assuming that most of the load is transferred through the side resistance caused by the contact between the pile and rock, and the remaining load is transferred through the base resistance of the bedrock [1]. However, because of the thick sediment at the bottom of the pile, the end resistance will be affected and 
its prediction becomes unreliable. Therefore, according to the existing bearing capacity calculation method [2], it is unsafe to consider the side resistance and end resistance at the same time to determine the bearing capacity of a single pile when a percussive drilling method is used.

There are many theoretical and experimental studies on the bearing capacity of rock-socketed piles [3]. For the bearing characteristics of rock-socketed piles, scholars in China and abroad have performed a series of studies. Field and laboratory tests are often performed to determine the load transfer function and load-settlement curve of the pile and, hence, to determine the bearing capacity of the pile. In this respect, the research was pioneered in the United States by Seed and Reese, who proposed that the relationship between side friction and pile settlement was hyperbolic. The study regarded a rock-socketed pile as composed of many elastic elements. Each element and the soil would meet a certain relationship, which is usually expressed by a load transfer function or curve. Then, according to the static equilibrium relationship of each element of the pile body, a basic differential balance equation was established [4]. According to the measured load displacement curve, a hyperbolic load transfer function was adopted for the side and the end resistance, and a numerical solution of the pile side resistance and base resistance was discussed [5]. Liu et al. conducted a vertical static load test and an internal force test on a rock-socketed pile and summarized the load-settlement curve of a rock-socketed pile, as well as the variation law of axial force and lateral resistance along the depth [6]. Barrett and Prendergast summarized the empirical relationship between the compressive strength of the surrounding rock in the rock-socketed section and the bearing capacity of a single pile based on a large number of field load tests of rocksocketed piles [7].

In the early days of the studies on the bearing capacity of a rock-socketed pile, it was thought that the deeper the socket depth, the greater will be the resistance of the rocksocketed pile and the bearing capacity. However, with further studies, scholars realized that increasing the depth of a rock-socketed pile can effectively improve the bearing capacity only to a certain depth range, after which there is almost no effect on the bearing capacity of a single pile socket. This indicated that there would be an optimum depth for a rock-socketed pile [8].

The bearing capacity of a rock-socketed pile depends on several factors including the relative displacement between the pile and rock (soil), and the displacement is related to the rock stratum lithology, elastic modulus of pile concrete, section size, construction technology, and the degree of bottom cleaning at the pile end [9]. As many factors influence the performance of a pile and a rocksocketed cast-in-place pile has the characteristics of strong concealment, its bearing mechanism is also complex [10]. Through extensive engineering practice and numerical analysis, scholars have found that the roughness of the wall of the bored hole has the greatest influence on the bearing capacity of rock-socketed piles $[11,12]$.
Luo et al. investigated the shear behaviors between the bolt and grout material under different initial normal stress and normal stiffness of the borehole wall. The test results show that both initial normal stress and normal stiffness significantly influence the interface shear behavior [13].

A standard for the wall roughness was proposed in 1980. Based on the test data of rock-socketed pile embedded in sandstone, the roughness of the hole wall was divided into four grades, $R 1, R 2, R 3$, and $R 4$; they are smooth, general, rough, and very rough, respectively. When the integrity of rock around the pile is good and no open discontinuities exist in the rock mass, the relationship between the pile side resistance and the unconfined compressive strength of the rock meets the following relationship [14].

When the roughness is between $R 1$ and $R 3$,

$$
f=0.45 \sqrt{\sigma_{\mathrm{c}}} .
$$

When the side wall roughness is $R 4$,

$$
f=0.6 \sqrt{\sigma_{c}},
$$

where $f$ is the pile side resistance and $S_{c}$ is the unconfined compressive strength of rock [15].

Horrath introduced a roughness factor called RF to quantitatively describe the hole wall roughness and proposed a method to calculate the side resistance. Based on the study, the greater the roughness factor, the greater was the pile side resistance when other conditions remained same [16].

Although the static load test is the most reliable method to obtain the bearing capacity of piles [17], it is not suitable for all test schemes due to the limitation of cost, reaction system, and space [18]. Many researchers have investigated the bearing capacity of rock-socketed piles through numerical analysis. Numerical simulation analysis of a rocksocketed pile includes three parts mainly: rock mass, pile concrete, and pile-rock (soil) interface. The finite element method can be effectively used to calculate the bearing capacity and predict the settlement of a single pile [19]. Leong and Randolph used finite element analysis to study the response of the pile body, with particular attention to the shaft response with and without intimate base contact [20]. Alnuaim et al. took a friction pile as the research object and studied the characteristics of side friction resistance under vertical load until failure [21]. Seol et al. analyzed the coupling effect of soil resistance in the rock-socketed shaft by the elastic-plastic finite element method and studied the slip and shear load transfer characteristics of the pile-soil interface [22]. Yu et al. used plane strain model to simulate layered foundation and bedrock [23]. Zhang et al. used a numerical simulation method to analyze the dynamic response of a rock-socketed steel elevated vertical wharf [24]. Gamage took a pile raft foundation as the research object and performed detailed numerical analysis to investigate its load transfer and the influence of various factors on the pile raft behavior [25].

Existing calculation methods of bearing capacity of rocksocketed piles are as follows [26]: 


$$
\begin{aligned}
Q_{\mathrm{u}} & =Q_{\mathrm{su}}+Q_{\mathrm{ru}}+Q_{\mathrm{bu}} \\
& =u_{1} \sum_{1}^{n} \zeta_{\mathrm{si}} q_{\mathrm{sui}} L_{\mathrm{si}}+u_{2} \zeta_{\mathrm{r}} f_{\mathrm{rc}} h_{\mathrm{r}}+\zeta_{\mathrm{b}} f_{\mathrm{rc}} A_{\mathrm{b}},
\end{aligned}
$$

where $Q_{\mathrm{u}}$ represents the ultimate bearing capacity of a rocksocketed pile; $Q_{\mathrm{su}}$ and $Q_{\mathrm{ru}}$ represent the side resistance of the soil layer around the pile and socketed section; $Q_{b u}$ represents the bottom end resistance; $q_{\text {sui }}$ represents the ultimate side resistance of the soil layer " $i$ " around the pile; $\zeta_{\mathrm{si}}$ is a coefficient representing the degree of exertion of the soil layer's side resistance; and $\zeta_{\mathrm{r}}$ and $\zeta_{\mathrm{b}}$, represent correction coefficients. Moreover, $f_{\text {rc }}$ represents the compressive strength of bedrock; $u_{1}$ and $u_{2}$ represent the circumference of the pile in soil and rock, respectively; $L_{\mathrm{si}}$ represents the soil thickness; $h_{\mathrm{r}}$ represents the socketed depth; and $A_{\mathrm{b}}$ represents the area of the pile bottom.

In summary, due to the lack of consideration of adverse effects of sediment in the rock-socketed pile design methods, existing research has difficulty to provide theoretical basis for the design of rock-socketed piles involving sediment at the pile bottom. Therefore, the bearing capacity of a pile was overestimated in the calculation (equation (3)). To overcome the current design flaws, this study conducts on-site tests to analyze the sediment thickness and bearing capacity of rock-socketed piles with impact hole forming. The sediment thickness, rock strength, pile-rock interface differences, and other factors are considered. The bearing performance of rocksocketed piles is analyzed numerically, and the influence of various factors on the bearing performance of rocksocketed piles with thick sediments is discussed. This paper proposes a method for calculating the bearing capacity and demonstrates the method through a design calculation for the rock-socketed pile for theoretical understanding.

\section{Bearing Performance and Field Test Study of Rock-Socketed Piles}

Firstly, a core pulling test was conducted to verify the sediment thickness at the bottom of a rock-socketed pile when a percussive drilling method was used in the weak cemented soil layer. Then, the vertical load test of the rocksocketed pile with thick sediment at the bottom of the pile was performed to verify the influence of sediment on the bearing capacity of the rock-socketed pile.

Table 1 shows the stratigraphic distribution of a mineproduced warehouse site in Shaanxi, China. The depth of the groundwater level exceeds $7.00 \mathrm{~m}$. This project adopted bored concrete piles. The pile diameter was $1.20 \mathrm{~m}$, and the concrete strength grade was C30. The construction adopted the impact hole-forming method, and the depth of the pile end entered the medium weathering rock layer at a depth of $1.50 \mathrm{~m}$. Before the steel cage was placed, the hole was mechanically cleaned according to the construction regulations.

Even though the pile hole was strictly cleaned by mechanical measures, weakly cemented soil and the gravel layer around the pile were collapsed when placing the steel cage after clearing the hole. Twelve piles were randomly selected for the borehole core pulling test. One sample for each test pile was drilled $0.15 \mathrm{~m}$ away from the center of the pile. A drilled sample was placed into a sample box from top to bottom, and the drilling conditions and abnormal drilling situation were recorded. The core concrete, pile bottom sediment, and pile end holding layer were recorded in detail. According to the test result, the concrete core samples of each sampled pile were continuous and complete. The sediment thickness at the bottom of the pile was between $0.38 \mathrm{~m}$ and $0.89 \mathrm{~m}$, as shown in Table 2. The composition of sediment was mainly pebble-mixed soil (Table 2 ).

When a weakly cemented layer was encountered around the pile and the impact hole-forming method was used for construction, thick sediment was generally present at the bottom of the pile (Table 2). The static load test results of the rock-socketed pile with the thickest sediment at the bottom of the pile were analyzed. Pile 6 , pile 9 , and pile 11 were taken for a pile static load test, as shown in Figure 1. The slowspeed maintenance load method was adopted; each stage increases $870 \mathrm{kN}$, and the first stage load was $1740 \mathrm{kN}$. The settlement at 5, 15, 30, 45, and 60 minutes after the load was applied was observed. When settlement less than $0.1 \mathrm{~mm}$ in one hour, it could be considered that the test pile was stable and the next load could be continued. When the settlement at the certain load is greater than 5 times at the previous load, it was regarded as the failure of the test pile and the loading terminated [6]. The test reaction force was weighed by the anchor pile and steel beam, pressurized by using a hydraulic jack, measured by using a pressure gauge, and observed for settlement by using a dial indicator. The load-settlement curves (Figure 2) show that, during the later stage of loading, the settlement of the three piles increased sharply, and the settlement was not stable.

At the initial stage of loading, the load-settlement curve of the three test piles was relatively gentle and the settlement was comparatively low. However, when the load reached a certain value and the relative pile-soil displacement increased, the ultimate friction resistance at the pile side was exceeded, and the pile suddenly lost stability followed by sinking (Figure 2).

According to the load-settlement (Q-s) curves shown in Figure 2, the load value corresponding to the initiation point of the curve falling obviously can be regarded as the ultimate bearing capacity. Therefore, the ultimate bearing capacity against vertical load of pile 6 and pile 9 was $6960 \mathrm{kN}$, and the vertical compressive ultimate bearing capacity of pile 11 was $7830 \mathrm{kN}$. According to the existing design method (equation (3)) of rock-socketed piles, the vertical compressive ultimate bearing capacity of a single pile composed of side resistance and end resistance would be $10440 \mathrm{kN}$. Compared to the calculated value, the ultimate bearing capacity of the three rock-socketed piles was significantly reduced when there was a thick layer of sediment at the bottom of the piles. This discrepancy suggests that when the impact hole-forming method is used for constructing a pile and weakly cemented layer is present around the pile, it is unsafe to determine the bearing capacity according to the existing design methods. 
TABLE 1: Stratigraphic distribution of the piling area.

\begin{tabular}{lccc}
\hline Number & Depth of the soil layer $(\mathrm{m})$ & Cumulative depth $(\mathrm{m})$ & Soil layer type \\
\hline (1) & $0.80-2.50$ & $0.80-2.50$ & Plain fill \\
(2) & $2.50-5.10$ & $3.30-7.60$ & Loess-like soil \\
(3) & $1.40-7.20$ & $4.70-14.80$ & Mixed soil \\
(4) & $0.00-3.20$ & $4.70-18.00$ & Silty clay \\
(5) & $2.50-2.80$ & $7.20-20.8$ & Circular gravel \\
(6) & $0.30-1.80$ & $7.50-22.60$ & Highly weathered sandstone \\
\hline
\end{tabular}

TABle 2: Logs of the twelve bore holes.

\begin{tabular}{lcccccccccccc}
\hline Pile number & 1 & 2 & 3 & 4 & 5 & 6 & 7 & 8 & 9 & 10 & 11 & 12 \\
\hline Pile length (m) & 12.42 & 12.58 & 12.65 & 12.56 & 12.28 & 11.82 & 13.27 & 12.82 & 11.56 & 12.61 & 11.65 & 12.66 \\
Sediment thickness (m) & 0.45 & 0.48 & 0.73 & 0.59 & 0.66 & 0.81 & 0.38 & 0.43 & 0.89 & 0.56 & 0.75 & 0.42 \\
Bearing stratum & \multicolumn{8}{c}{ Medium weathered sandstone, reddish brown, complete core } \\
\hline
\end{tabular}

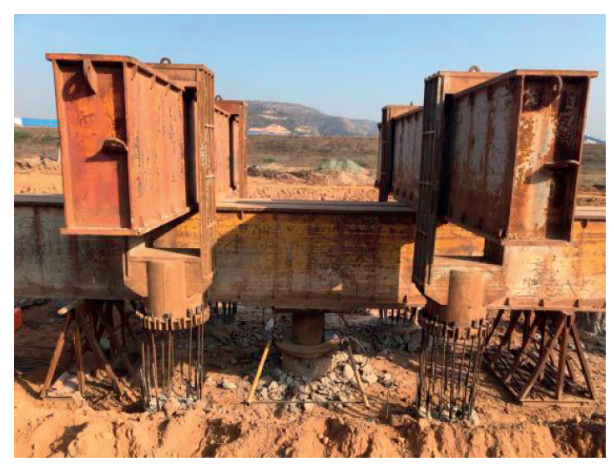

Figure 1: Static load test of the pile.

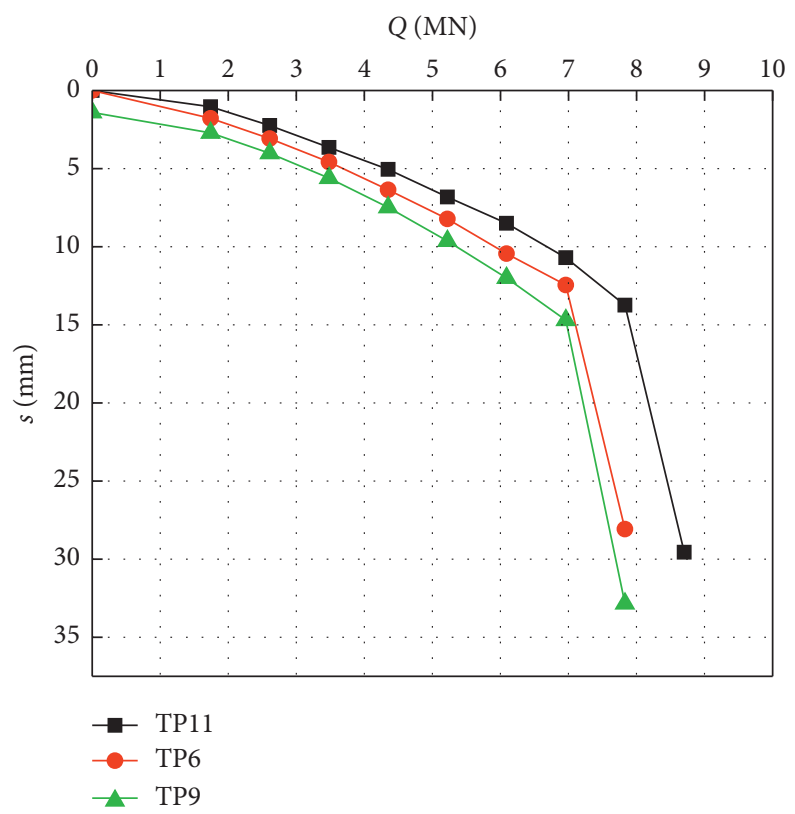

Figure 2: Load-settlement curves of the three piles tested for static load. 


\section{Numerical Analysis of the Bearing Capacity of a Rock-Socketed Section}

According to the abovementioned analysis, the pile bearing capacity was affected by the presence of pile bottom sediment. In order to further study the influence of sediment on pile bearing characteristics at different construction, the finite element simulation method was used in different socketed depths and surrounding rock to analyze the stress and displacement at any desired location of the pile body. Therefore, the bearing characteristics such as friction distribution and deformation of the rock-socketed section were studied by performing a finite element analysis. The following sections discuss the numerical analysis used to study the distribution and deformation of the rock-socketed section.

3.1. Research Plan. In this paper, the static load test under different rock-socketed depths and different surrounding rock strengths was simulated. The pile-rock interface was taken in a tightly occluded state. The concrete grade of the pile body was taken as C30, and the bedrock was considered as soft rock. The pile diameter was taken as 1 meter, and the sediment thickness was taken as 1 meter. The bearing capacity of a rock-socketed pile is an axisymmetric problem, and hence, axisymmetric modeling was used. In order to simulate the influence of sediment at the bottom of the pile on the bearing properties of the pile, the stiffness of sediment at the bottom of the pile was not considered, and the pile bottom was set to be suspended. The rock-socketed pile was taken as an elastic material, and the rock mass was considered as an ideal elastic-plastic material that followed the Mohr-Coulomb strength criterion. The contact morphology and mechanical parameters of piles, rock layers, and contact surfaces in the model were selected according to the problems studied. In order to simulate the process of an impact forming hole, the roughness of the hole wall was considered in the analysis. A good contact was assumed between the pile and rock, and the interface between the pile and rock was simulated in the form shown in Figure 3.

The model is shown in Figure 4, and it is simplified as an axisymmetric problem. In the finite element model, the mesh division of the model adopted the density control technology. Accordingly, the mesh near the pile-rock interface was the finest, and the mesh farther away from the interaction surface was the coarsest.

\subsection{Influence of Rock-Insertion Depth on Bearing Properties.} In order to study the influence of different rock-socketed depths on the bearing behavior, the rock-socketed depth was varied as $1 \mathrm{~m}, 2 \mathrm{~m}, 3 \mathrm{~m}$, and $4 \mathrm{~m}$. According to relevant literature data [27], the mechanical parameters of pile concrete and bedrock were taken as shown in Table 3. The Q$s$ curve of the pile, the distribution of pile side friction, and the distribution of the axial force of the pile body in the depth direction at different rock-insertion depths were calculated and are shown in Figure 5. The distribution of side friction along the depth is bimodal, which is consistent with

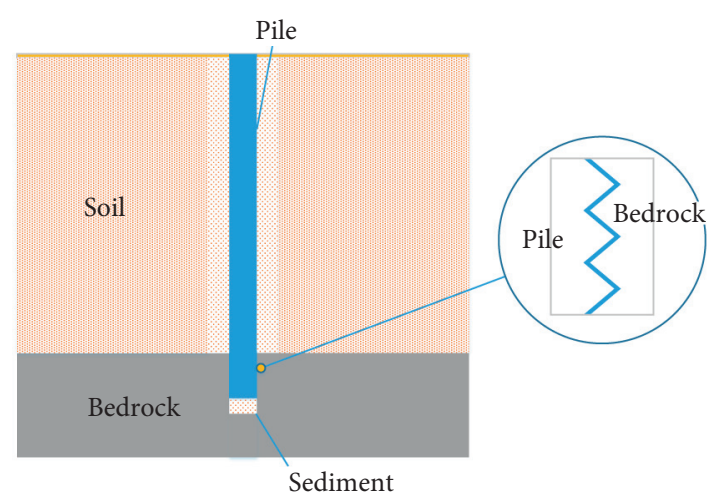

Figure 3: Contact between a pile and rock.

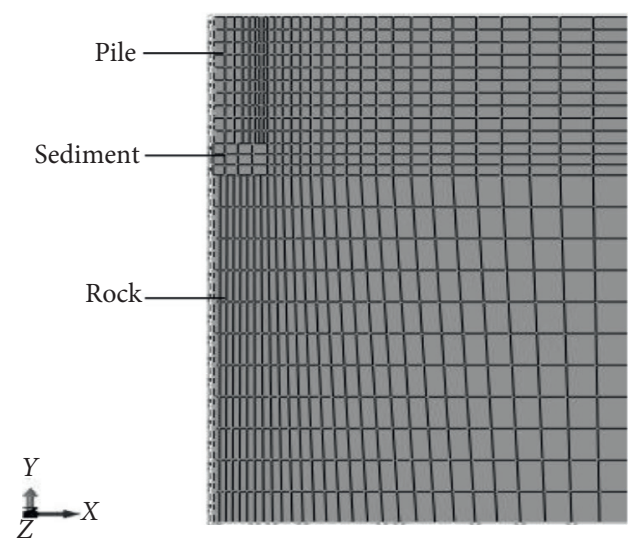

FIgURE 4: Finite-element mesh.

TABle 3: Properties of piles and rock adopted in the numerical analysis.

\begin{tabular}{lcc}
\hline Parameters & Pile & Rock \\
\hline Pile diameter $(\mathrm{m})$ & 1 & - \\
Rock-insertion depth $(\mathrm{m})$ & $1,2,3,4$ & - \\
Modulus of elasticity E $(\mathrm{GPa})$ & 30 & 5 \\
Poisson's ratio $u$ & 0.2 & 0.22 \\
Cohesion $c(\mathrm{kPa})$ & - & 520 \\
Friction angle $\varphi\left(^{\circ}\right)$ & - & 41 \\
\hline
\end{tabular}

the existing research results [28]. This verifies the validity of the simulation results.

As shown in Figure 5, the rock-socketed pile did not fail under a vertical load. Displacement increased gradually with an increase in load, but sharp rise of settlement was not observed (Figure 5(a)). The settlement of the pile was significantly influenced by the socketed depth when the depth increased from $1.00 \mathrm{~m}$ to $3.00 \mathrm{~m}$. With an increase in the length of the rock-socketed section, the total side resistance of the rock-socketed section increased, which increased the bearing capacity of a single pile and reduced the settlement of the pile. However, settlement was not reduced significantly when the rock-socketed depth was increased from 3 to $4 \mathrm{~m}$. This proved that an optimum value exists for the 


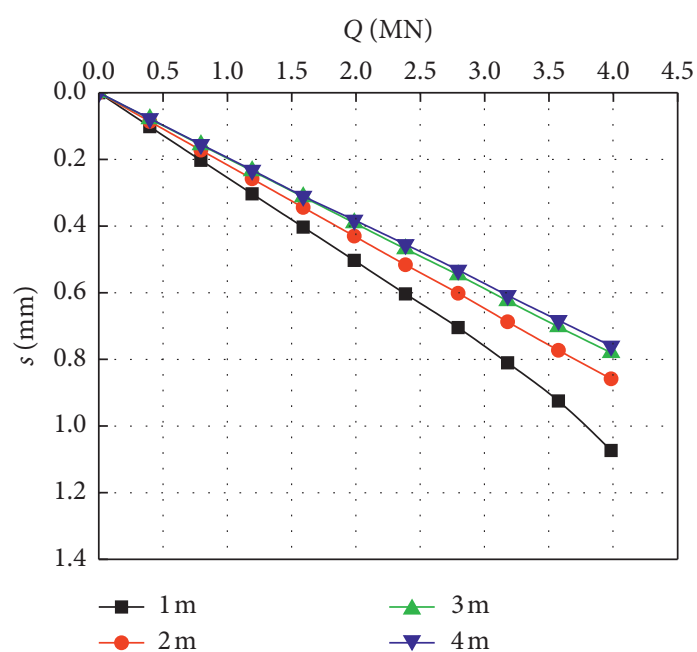

(a)

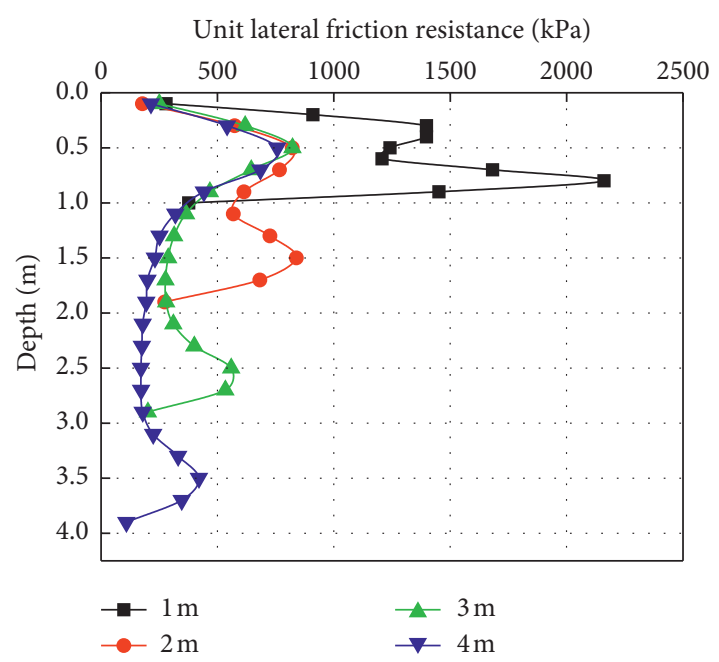

(b)

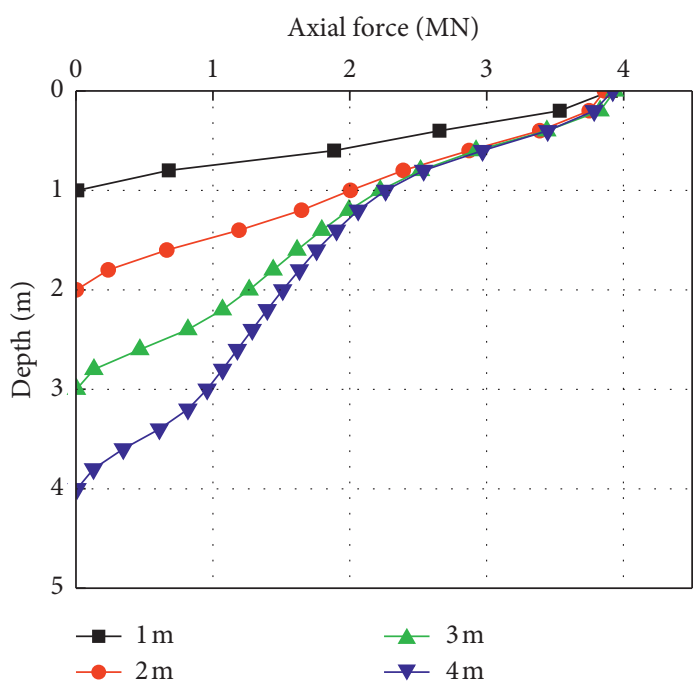

(c)

FIGURE 5: Bearing characteristics of a rock-socketed pile with various rock-socketed depths. (a) Load settlement curve. (b) Shaft friction distribution curve. (c) Axial force distribution curve.

socketed depth of a rock-socketed pile. Increasing the rocksocketed depth within the optimum depth range can effectively control the settlement, and beyond this depth, settlement is not reduced by increasing the rock-socketed depth. When settlement is regarded as one of the main controlling parameters to determine the bearing capacity, increasing the rock-socketed depth within the optimal depth range is an effective way to improve the bearing capacity.

Under the action of the maximum load, the unit side friction of the pile was distributed in the shape of a saddle along the depth (Figure 5(b)), but the distribution trend of the unit side friction was different for different socketed depths. Only when the rock-socketed depth was especially less, the lower peak of the rock-socketed section was higher than the upper peak. This is related to the difference in settlement reflected in Figure 5(a). The smaller the rocksocketed depth, the greater the pile settlement, so the corresponding pile-rock relative displacement was larger, and the pile side friction was fully exerted. Therefore, when the rock-socketed depth was smaller, the peak value of the side friction was greater than that of other piles.

When the socketed depth was relatively small, the lower peak of the rock-socketed section was smaller than the upper peak. With an increase in the rock-socketed depth, side friction was fully developed in the upper portion. Since most of the load was resisted by the friction in the upper portion, side friction could not be fully developed in the lower part. This is attributed to the increase in rock-socketed depth, which decreased the pile settlement and, hence, reduced the pile-rock relative displacement. Therefore, the decrease of unit side friction would require an increased rock-socketed depth. Because the axial force of the pile body decreased gradually with an increase in the depth, according to the equilibrium of force, the unit side friction at the top of pile was the largest, and the unit side friction gradually decreased with an increase in the depth. However, due to the trend of 
increased sinking of the pile at the pile end, the side friction at the lower part of the rock-socketed section was mobilized, and the side friction increased near the pile end.

Figure 5(c) shows the axial force distribution of the rocksocketed pile shaft when the maximum load was applied. It can be seen that the axial force of the pile shaft gradually decreased from the pile top load to zero along the depth direction. The axial force at the end of the pile was zero, indicating that no end resistance was exerted.

When the rock-socketed depth was small, the friction attenuation speed was faster. Because the relative displacement of pile-rock displacement was relatively large, the friction resistance of the pile side was larger, and the rate of transfer of the axial force from the pile to the surrounding rock was faster. With an increase in rock-socketed depth, the pile-rock relative displacement decreased, the pile side friction gradually decreased, and the rate of transfer of the axial force from the pile to the surrounding rock decreased. Thus, the stress attenuation of the pile body was slowed down with an increase in the rock-socketed depth, which corresponded to the smaller friction resistance.

\subsection{Influence of Bedrock Strength on Bearing Properties.} In order to study and compare the influence of bedrock strength on the bearing performance of thick-sediment rock-socketed piles, four different bedrock strengths were selected for the numerical analysis. The depth of the pile body embedded in rock was $2 \mathrm{~m}$, the diameter of the pile was $1 \mathrm{~m}$, and the load at the top of the pile was $4 \mathrm{MN}$. The calculation parameters for bedrock with four different strengths are shown in Table 4. The modulus and other parameters of rock were determined by referring to the engineering geological manual and literature data [2].

Figure 6(a)-6(c), respectively, show the load-settlement curves for four bedrock strengths, the distribution of frictional forces on the side of the pile, and the axial force distribution of the pile body along the depth.

For the four strengths of bedrock considered in this study, the rock-socketed pile did not yield and the settlement changed slowly with the load (Figure 6(a)). For a given applied load, the amount of pile settlement was significantly affected by the strength of the bedrock. The settlement of the rock-socketed pile decreased with an increase in the strength of bedrock. With an increase in pile top load, the difference in settlement caused by the difference in bedrock strength was more pronounced. When settlement was taken as one of the main controlling parameters to determine the bearing capacity, the bearing capacity appeared highly sensitive to the strength of bedrock: the higher the strength of bedrock, the higher the bearing capacity. Since the strength of the pile was greater than the strength of the surrounding rock, when the pilerock interface was sheared, it was assumed that the failure occurred due to the compression failure of the surrounding rock. Therefore, under a certain load, when the strength of the surrounding rock is relatively large, the compression of the surrounding rock is relatively small, and the settlement of the pile is relatively small.
TABle 4: Properties of concrete and rock.

\begin{tabular}{lcc}
\hline Parameters & Pile & Rock \\
\hline Pile diameter $(\mathrm{m})$ & 1 & - \\
Rock-insertion depth $(\mathrm{m})$ & 2 & - \\
Modulus of elasticity $E(\mathrm{GPa})$ & 30 & $1,2.5,5,10$ \\
Poisson's ratio $u$ & 0.2 & 0.22 \\
Cohesion $c(\mathrm{kPa})$ & - & $340,400,520,720$ \\
Friction angle $\varphi\left(^{\circ}\right)$ & - & $33,36,41,45$ \\
\hline
\end{tabular}

For a relatively large load applied to the rock-socketed pile, the distribution of unit side friction of the rocksocketed section was saddle shaped along the depth. The trend of variation of the friction was influenced by the strength of the bedrock (Figure 6(b)). When the bedrock was weak, the distribution of unit side friction of the pile was saddle shaped and the unit side friction of the upper part of the rock-socketed section was smaller than that of the lower part. When the rock was strong, the unit side friction resistance of the pile still showed a saddle-type distribution but the unit side friction resistance of the upper part of the rocksocketed section was greater than that of the lower part. The center of gravity of the unit side friction distribution curve shifted towards the upper part of the rock-socketed section.

Based on the distribution of the axial force of the pile body shown in Figure 6(c), due to the existence of sediment at the bottom of the pile, total applied load was resisted by side friction. At the bottom of the rock-socketed section, the axial force of the pile body was zero. The axial force of the pile body decreased gradually from the applied load to zero along the depth direction. Comparing four piles otherwise identical but with different bedrock strengths, when the strength of the bedrock was higher, the friction at the upper part of the rock-socketed section was larger, and the axial force of the pile body at the same depth was smaller. This observation suggests that the axial force of the pile body becomes smaller when the strength of the bedrock is greater.

\section{Theoretical Equation for the Side Friction of a Rock-Socketed Pile}

4.1. Pile Side Friction. During the pouring process of a rocksocketed pile, the cement slurry at the interface is cemented with the rock wall. When the pile-rock relative displacement does not occur or the relative displacement is less, there are different degrees of cementation strength on the contact surface [29]. Further study by Jonhston et al. showed that when shearing occurs along the interface, there are two kinds of shear mechanisms: sliding shear expansion and sliding shear [9]. In the process of the impact hole-forming method, the wall of the hole becomes a rough surface, which enhances the friction of the pile-rock interface. In the initial stage of loading, as shown in Figure 7, no or less relative displacement occurs between the pile and rock, and the contact interface is in the bonding stage. When the axial force of the pile exceeds the cementation strength of the pile-rock interface, the pile body will slide along the rough surface of the wall of the hole and cause the pile hole to expand radially, which is the sliding shear expansion mechanism. According 

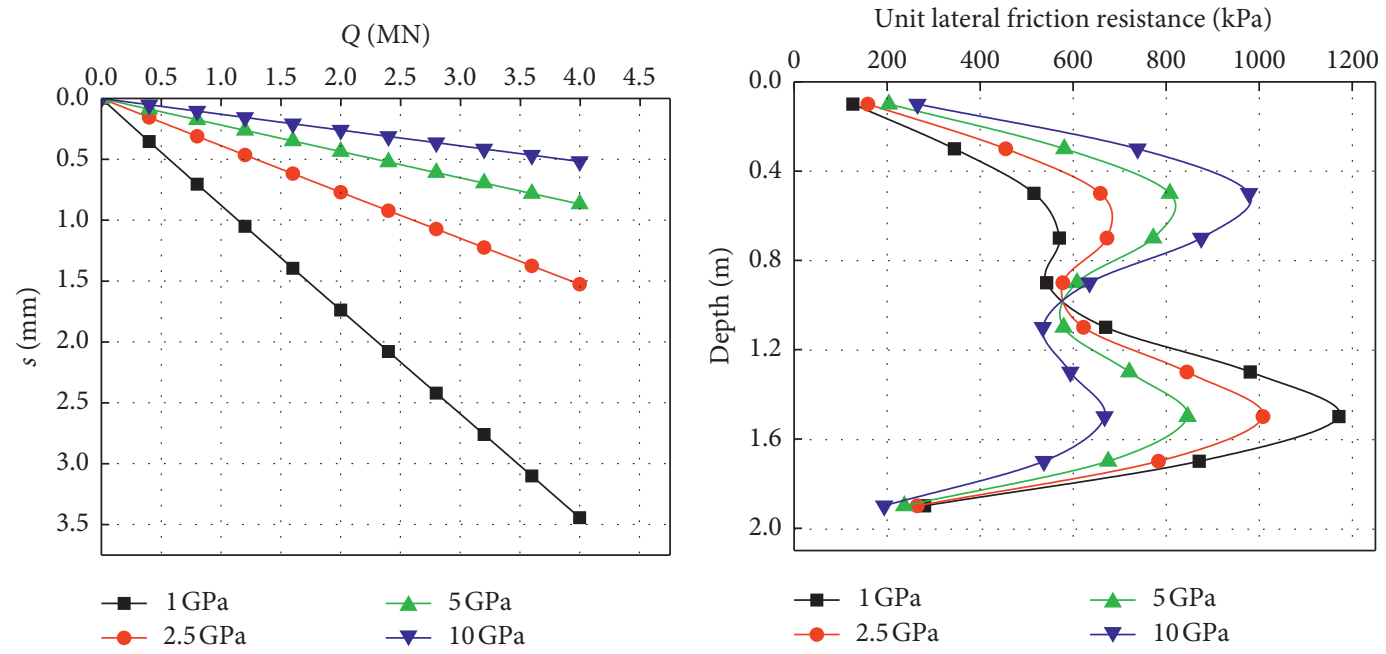

(a)

(b)

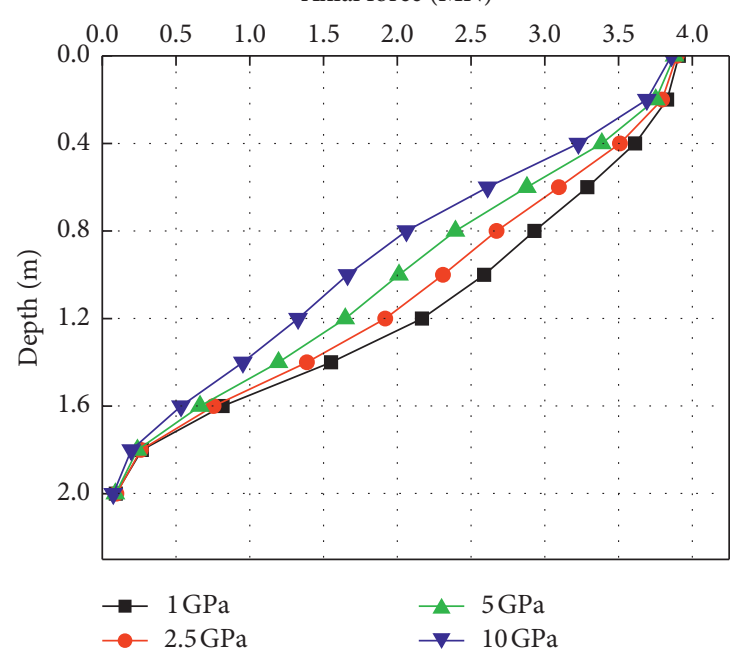

(c)

Figure 6: Bearing characteristics of a rock-socketed pile for different bedrock strengths. (a) Load-settlement curve. (b) Shaft friction distribution curve. (c) Axial distribution curve.

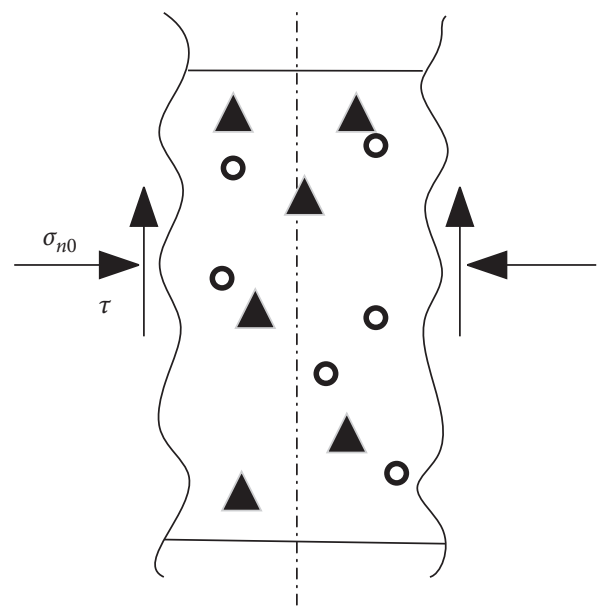

(a)

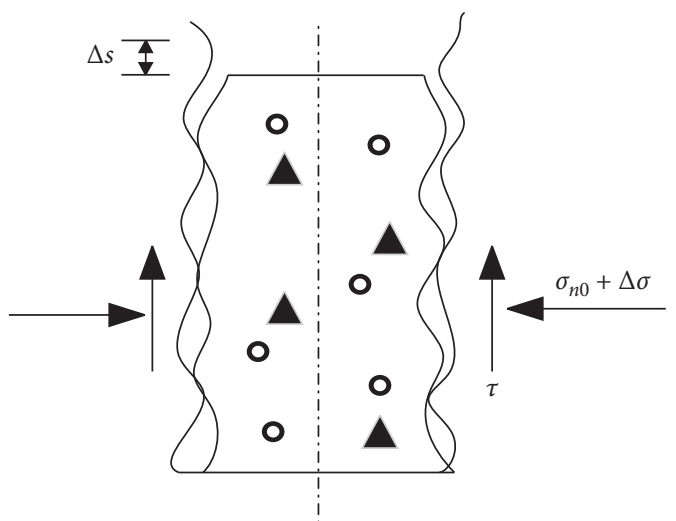

(b)

FIgURE 7: Sliding shear behavior of a rock-socketed pile. (a) Before sliding. (b) After sliding. 
to the cavity expansion theory, the normal stress increment will be produced in the process of pile sliding expansion, which, in turn, will increase the shear stress. With an increase in the applied load, the relative displacement and shear stress further increase. When the shear stress exceeds the shear strength of the bulge of the wall, the bulge will be sheared and a new sliding surface will be formed. The pile then slides along the newly formed interface, which is the shear slip mechanism.

As the stress of the pile body decreases gradually along the depth of the pile, the relative displacement of the pile and rock decreases with an increase in rocksocketed depth. Therefore, the unit side friction gradually decreases along the depth of the socketed part. Furthermore, the governing failure mechanism of the rock-socketed part can be changed from shear slip to sliding shear expansion to cementation failure with an increase in socket depth. According to the unit side friction distribution curve in Section 3, when the rocksocketed depth is small, the pile body settlement is large. Accordingly, the rock wall bulge is quickly cut off, and the pile-rock shear behavior only includes shear slip and cementation failure.

According to the Coulomb friction law, the friction $Q_{\mathrm{s}}$ of the pile-rock interface varies linearly with the lateral pressure $P$ as follows:

$$
Q_{s}=C+\mu P,
$$

where $C$ represents the cohesion force of the pile-rock interface and $\mu$ represents the friction coefficient. Therefore, determination of interface friction needs three factors, namely, cohesion force, friction coefficient of the interface, and lateral pressure. For a cast-in-place pile, the cohesion force between the pile and rock is governed mainly by two aspects: first, adhesion between the pile and the rock during concrete pouring and, second, mechanical occlusion mechanism. After a hole is formed, the wall of the hole is usually rough. When the pile slides relative to the rock, the pile hole will expand. The expansion of the pile hole results in an increase in the normal stress of the interface. The side friction of the socket is mainly caused by the lateral pressure and the expansive stress of the surrounding rock. For the convenience of theoretical derivation, the following assumptions are made:

(1) The pile-rock interface is a regular zigzag undulating surface with an undulating angle of $\theta$

(2) The surrounding rock fails prior to the pile failure, and the failure surface is parallel to the displacement direction of the pile

Based on the abovementioned assumptions, the pilerock shearing process is divided into three stages, and the three-stage functions are used to describe the shear stress and displacement relationship of the pile-rock interface.

4.1.1. Bond Damage. He used a two-stage linear function to describe the shear stress and shear displacement relationship on the interface between rock and pile concrete [30]. The linear function of the first stage can better reflect the shear characteristics of the pile-rock cross section in the cementation failure stage. Therefore, in this paper, the linear function of the first stage is used to characterize the cementation failure. The corresponding stress-slip relationship can be written as follows:

$$
\tau(z)=K_{1} \triangle s, \quad(0<\Delta s \leq w) .
$$

The relative displacement of pile-rock at different socketed depths is

$$
\triangle s=s_{\mathrm{d}}-\frac{1}{\mathrm{EA}} \int_{0}^{z} \mathrm{Q}(z) \mathrm{d} z,
$$

where $\tau$ represents the shear stress and $K_{1}$ represents the bond stiffness. The relative displacement of pile-rock at depth $z$ is $\Delta s$, and $s_{\mathrm{d}}$ is the settlement of the pile top. $E$ represents the elastic modulus of the pile, and $A$ represents the area of the pile top. The ultimate bond strength $\left(C_{\mathrm{b}}\right)$ of the rock-socketed section can be obtained by a direct shear test of the interface between concrete and rock. Then, the maximum relative displacement of pile and rock at the time of cementation failure is

$$
w=\frac{C_{\mathrm{b}}}{K_{1}} .
$$

4.1.2. Sliding Shear Expansion. When the friction force of the pile side exceeds the bond strength, sliding shear expansion will occur. Assuming that the rock is in the elastic deformation stage under the action of expansion, the constitutive physical equation of the elastic stage can be used. Accordingly, the normal stress increment corresponding to the radial expansion of the hole wall under the axisymmetric condition is, thus, calculated as follows:

$$
\sigma_{r}=\frac{E_{\mathrm{r}}}{(1+v) r} \Delta r
$$

where $E_{\mathrm{r}}$ represents the elastic modulus of rock; $v$ represents Poisson's ratio; and $r$ represents the diameter of pile hole.

The term $E_{\mathrm{r}} /[(1+v) r]$ in eq. (8) can be substituted by $K$, which is the normal stiffness of surrounding rock. As shown in Figure 8, the undulating angle of the pile-rock interface is assumed as $\theta$. Hence, the radial expansion is calculated as follows:

$$
\triangle r=\triangle s \tan \theta
$$

Moreover, according to equation (7), the expansion stress of rock is calculated as follows:

$$
\sigma_{r}=K \triangle s \tan \theta, \quad\left(w<\triangle s \leq s_{0}\right) .
$$

The normal stress of the pile-rock interface is the cumulative value of the initial stress and the expansive stress of the surrounding rock. It should be noted that when calculating the normal stress, the initial stress should also be considered. The initial stress is 


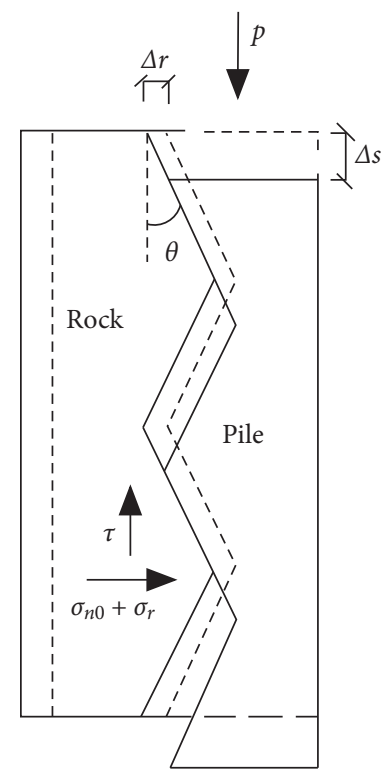

(a)

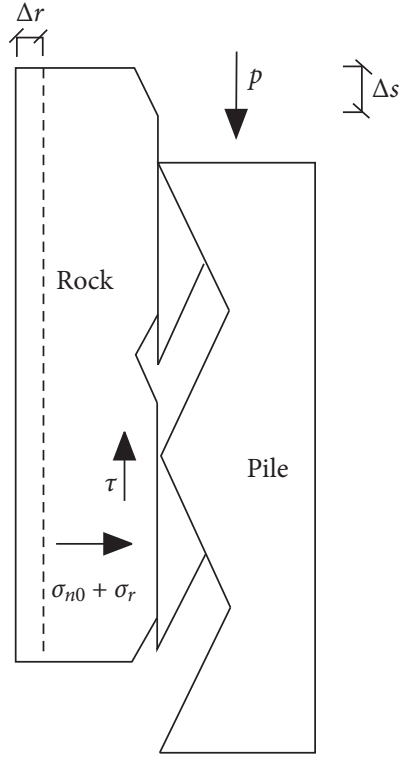

(b)

FIgUre 8: Process of slippage shear. (a) Sliding shear expansion. (b) Shear slip.

$$
\sigma_{n 0}=K_{0} \gamma z
$$

Therefore, the normal stress of the pile-rock interface, $\sigma_{n}$, is expressed by the following equation:

$$
\sigma_{n}=\sigma_{n 0}+\sigma_{r}
$$

Patton studied the shear strength of rock discontinuities with regular rough undulation and no filler and proposed an expression for the shear strength of rock discontinuities with small normal stress as follows [31]:

$$
\tau=\sigma_{n} \tan \left(\varphi_{\mathrm{b}}+\theta\right)
$$

where $\varphi_{\mathrm{b}}$ is the basic friction angle of the structural plane. When the normal stress increases gradually and the shear strength of the structural plane reaches the ultimate shear strength, then

$$
\tau_{1}=c+\sigma_{n} \tan \varphi,
$$

where $C$ and $\varphi$ represent the cohesion and friction angle of rock, respectively.

According to equations (11) (13), when the relative displacement of the pile-rock interface at a depth $z$ is $\Delta s$, the shear stress is calculated by the following equation:

$$
\tau(z)=\left(\sigma_{n 0}+K \triangle s \tan \theta\right) \tan \left(\varphi_{b}+\theta\right), \quad\left(w<\Delta s \leq s_{0}\right) .
$$

During the loading process, the shear stress generated by the sliding movement of the pile exceeds the shear strength of the rock bulge and the rock bulge will be sheared. In this condition, equation (13) and equation (14) become identical, and the critical normal stress condition of the shearing convex body can be obtained as follows:

$$
\sigma_{1}=\frac{C}{\tan \left(\varphi_{b}+\theta\right)-\tan \varphi}
$$

Similarly, equation (12) = equation (16) define the stress boundary between the elastic zone and the plastic failure zone.

$$
\sigma_{1}=\frac{C}{\tan \left(\varphi_{b}+\theta\right)-\tan \varphi}=\sigma_{n 0}+K s_{0} \tan \theta
$$

Thus, we have

$$
s_{0}=\frac{c}{K \tan \theta\left(\tan \left(\varphi_{b}+\theta\right)-\tan \varphi\right)}-\frac{\sigma_{n 0}}{K \tan \theta} .
$$

From equation (18), the limiting displacement in the sliding shear expansion stage can be obtained. It can be seen from the equation that the initial stress has a certain influence on the ultimate displacement. Under certain conditions of surrounding rock stiffness and dilatancy angle, the initial stress contributes to reduce the ultimate shear displacement.

4.1.3. Shear Slipping. When the relative sliding of pile and rock reaches $s_{0}$, the convex part of rock is destroyed and the hole wall is no more expanding. As shown in Figure 7(b), a new pile-rock friction surface is formed, and the pile continues to slide along the new sliding surface until it becomes stable. The friction angle of the interface is the residual friction angle $\varphi_{\mathrm{r}}$. The normal stress of the pile side can be obtained as follows:

$$
\sigma_{n}=\sigma_{n 0}+K s_{0} \tan \theta, \quad\left(\triangle s \geq s_{0}\right) .
$$

The shear stress at different depths is, thus, calculated as follows: 


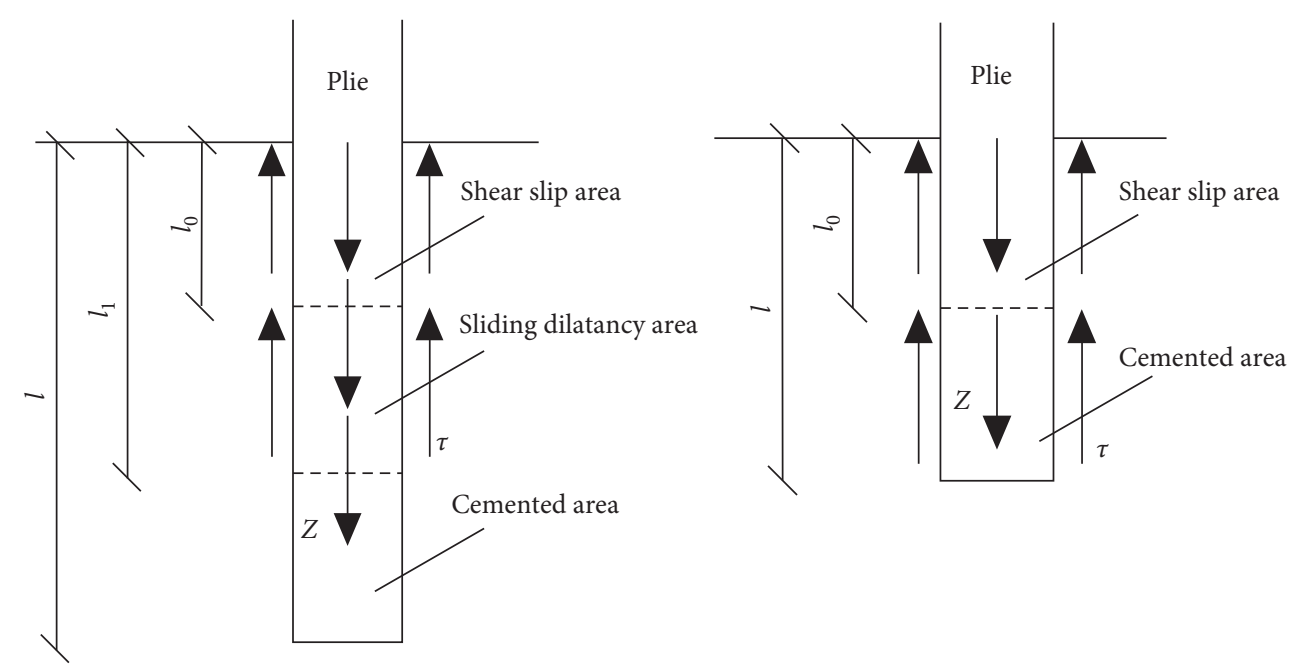

Figure 9: Computation diagram of the skin friction of a pile.

$$
\tau(z)=\left(\sigma_{n 0}+K S_{0} \tan \theta\right) \tan \left(\varphi_{r}\right), \quad\left(\triangle S \geq S_{0}\right) .
$$

Based on the abovementioned analysis, a complete expression of pile side friction of the socketed pile-rock interface can be obtained as follows:

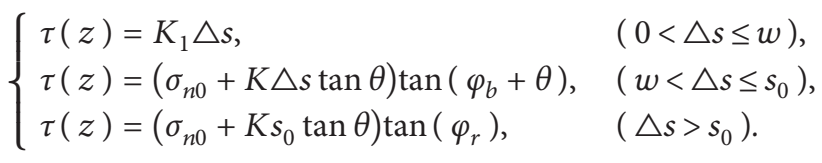

Hence, the complete functional expression of the stress constitutive model of a socketed pile-rock interface was obtained. It can reflect the influence of the pile diameter, rock elastic modulus, and rock wall roughness on the pile side friction. Therefore, equation (21) can better represent the load transfer behavior of the rock-socketed section.

4.2. Calculation of the Single Pile Bearing Capacity. As shown in Figure 9, assuming that the rock-socketed pile conforms to the shear characteristics of a complete structural surface, the loading characteristics of the pile-rock interface along the rock-socketed depth can be divided into (a) a shear slip zone having the depth of failure zone as $l_{0}$ and its shear displacement as $\Delta s>s_{0}$; (b) a sliding shear expansion zone having the depth of failure zone as $l_{0}$ to $l_{1}$ and its shear displacement as $w_{1}<\Delta$ and $s<s_{0}$; and (c) a cementation zone having the depth range as $l_{1}$ to $l$ and its shear deformation as $0<\Delta s<w_{1}$. When the rock-socketed section is short, the pile produces a large displacement and the rock wall bulge is quickly sheared. Therefore, when the rocksocketed depth is shallow, the shear behavior of the pile-rock interface is dominated by the shear slip behavior and cementation behavior. We suppose that the load acting on the pile top is $P_{\mathrm{d}}$, the settlement of pile top is $s_{\mathrm{d}}$, the thickness of soil layer is $l_{\mathrm{s}}$, and the length of rock-socketed section is $l$. For the convenience of calculation, it is assumed that the lateral resistance of the overlying soil to the pile side is $Q_{\text {su }}$.

According to the deformation characteristics of different shear zones of rock-socketed piles, at a depth of $l_{0}$, the surrounding rock mass beside the pile is the boundary between the shear zone and the shear expansion zone, and the displacement continuity condition is satisfied. Thus,

$$
\frac{c}{K \tan \theta\left(\tan \left(\varphi_{\mathrm{b}}+\theta\right)-\tan \varphi\right)}-\frac{\sigma_{n 0}}{K \tan \theta}=S_{\mathrm{d}}-\frac{P_{\mathrm{d}}\left(l_{\mathrm{s}}+l_{0}\right)}{E_{\mathrm{p}} A_{\mathrm{p}}}
$$

Equation (22) can be rearranged as

$$
l_{0}=\frac{E_{\mathrm{p}} A_{\mathrm{p}}}{P_{\mathrm{d}}}\left[S_{\mathrm{d}}-\frac{c-\sigma_{n 0}\left(\tan \left(\varphi_{\mathrm{b}}+\theta\right)-\tan \varphi\right.}{K \tan \theta\left[\tan \left(\varphi_{\mathrm{b}}+\theta\right)-\tan \varphi\right]}\right]-l_{\mathrm{s}} .
$$

At the rock-socketed depth $l_{1}$, which is the boundary between the cementation zone and the dilatancy zone, the displacement satisfies

$$
\frac{C_{\mathrm{b}}}{K_{1}}=S_{\mathrm{d}}-\frac{P_{\mathrm{d}}\left(l_{\mathrm{s}}+l_{1}\right)}{E_{\mathrm{P}} A_{\mathrm{P}}} .
$$

After rearranging equation (24), $l_{1}$ can be obtained as

$$
l_{1}=\frac{E_{\mathrm{P}} A_{\mathrm{P}}\left(S_{\mathrm{d}} K_{1}-C_{\mathrm{b}}\right)}{P_{\mathrm{d}} K_{1}}-l_{\mathrm{s}} \text {. }
$$

Therefore, according to the aforementioned lateral resistance distribution function, the bearing capacity of a single rock-socketed pile can be determined as

$$
\begin{aligned}
Q_{\mathrm{u}} & =Q_{\mathrm{su}}+Q_{\mathrm{ru}} \\
& =u_{1} \sum_{1}^{n} \zeta_{\mathrm{si}} q_{\mathrm{sui}} L_{\mathrm{si}}+u_{2}\left(\int_{0}^{l_{0}} \tau_{1}(z) \mathrm{d} z+\int_{l_{0}}^{l_{1}} \tau_{2}(z) \mathrm{d} z+\int_{l_{1}}^{l} \tau_{2}(z) \mathrm{d} z\right) .
\end{aligned}
$$


According to the abovementioned derivation process, the bearing capacity of a single rock-socketed pile can be obtained after determining the material properties, geometric conditions, surrounding rock properties, construction conditions, and other factors.

\section{Conclusions}

This paper investigated the bearing performance of a rocksocketed pile with sediment at the bottom of the pile. A core pulling test and static load test were performed on three rock-socketed piles, and numerical and theoretical analysis were performed. The following are the main conclusions:

(1) In a weakly cemented soil area, the rock-socketed pile driven by using the impact hole-forming method is associated with thick sediment at the bottom of pile that significantly affects the loadsettlement characteristics. When there was sediment at the bottom of the pile, the settlement at the top of the pile was gentle with an increase in load. However, when the load increased to a certain value, the settlement at the top of the pile dropped rapidly. The pile in the test had reached the ultimate bearing capacity well before the load reached the design value as calculated from currently practiced methods. Because of the presence of sediment, the side resistance played an important role, so only the side resistance should be considered in the design of a rock-socketed pile, or strict quality control helps to reduce risks related with sediment bottom of borehole before lacing of concrete.

(2) When socketed depth and bedrock strength were relatively low, the maximum value of side friction was greater for the lower half of the rock-socketed depth compared to the upper half. When the rocksocketed depth and bedrock strength were large, the peak value in the lower part of the rock-socketed section was smaller than that in the upper part. For a given pile top load, the smaller the rock-socketed depth, the larger the settlement. This favorably contributed to the mobilization of the side friction, so an increased amount of side friction was observed in the rock-socketed section.

(3) The axial force of the pile body gradually decreased to zero from the top to the bottom. The strength of sediment was very low, and it did not provide any reaction force for the pile as a bearing layer. The axial force at the pile end was zero.

(4) The complete shear mechanism of the pile-rock interface can be divided into cementation failure, sliding dilatancy, and shear sliding. Accordingly, its mechanical constitutive model can be expressed by three linear functions. A complete set of equations for calculating the bearing capacity of rock-socketed piles suitable for the presence of sediment in the pile hole was proposed.

\author{
Abbreviations \\ $f: \quad$ Side resistance \\ $S_{\mathrm{c}}$ : $\quad$ Unconfined compressive strength of rock \\ $Q_{\mathrm{u}}: \quad$ Ultimate bearing capacity of a rock-socketed pile \\ $Q_{\text {su: }}$ : Side resistance of the soil layer \\ $Q_{b u}$ : $\quad$ Side resistance of the socketed section \\ $Q_{b u}: \quad$ End resistance \\ $q_{\text {sui: }} \quad \quad \quad$ Ultimate side resistance of the soil layer \\ $\zeta_{\mathrm{si}}: \quad$ Degree of exertion of the soil layer's side \\ resistance \\ $\zeta_{\mathrm{r}}$ and $\zeta_{\mathrm{b}}$ : Correction coefficient \\ $f_{\mathrm{rc}}$ : $\quad$ Compressive strength of bedrock \\ $u_{1}$ and $u_{2}$ : Circumferences of a pile in soil and rock \\ $L_{\mathrm{si}}: \quad$ Soil thickness \\ $h_{\mathrm{r}}: \quad$ Socketed depth \\ $A_{\mathrm{b}}$ : $\quad$ Area of the pile bottom \\ $C: \quad$ Cohesion force of the pile-rock interface \\ $\mu$ : $\quad$ Friction coefficient \\ $P: \quad$ Lateral pressure \\ $\tau: \quad$ Shear stress \\ $K_{1}: \quad$ Bond stiffness \\ $\Delta s: \quad$ Relative displacement of pile-rock \\ $s_{\mathrm{d}}: \quad$ Settlement of the pile top \\ E: $\quad$ Elastic modulus of the pile \\ A: $\quad$ Area of the pile top \\ $w$ : $\quad$ Relative displacement of pile and rock when \\ maximum cohesive force is exerted \\ $s_{0}: \quad$ Dilatancy limiting displacement \\ $C_{\mathrm{b}}$ : $\quad$ Pile to rock bond strength \\ $E_{\mathrm{r}}: \quad$ Elastic modulus of rock \\ $v: \quad$ Poisson's ratio \\ $r: \quad$ Diameter of a pile hole \\ $K_{0}: \quad$ Side pressure coefficient \\ $\gamma: \quad$ Bulk density of rock \\ $\theta$ : $\quad$ Undulating angle of the pile-rock interface \\ $\Delta r: \quad$ Radial expansion \\ $\varphi_{\mathrm{b}}: \quad$ Basic friction angle of the contact surface \\ $\varphi: \quad$ Friction angle of rock.
}

\section{Data Availability}

All necessary data and models generated or used during the study appear in the submitted article. All data included in this study are available upon request by contact with the corresponding author.

\section{Conflicts of Interest}

The authors declare that they have no conflicts of interest.

\section{Acknowledgments}

This study was supported by the funding program of the National Natural Science Foundation of China. The authors would like to thank the team members of the Key Discipline of Geotechnical Engineering and the workers of the Geotechnical Engineering Laboratory. This work was supported 
by Key Research \& Development Program of Shaanxi in China (No. 2018ZDCXL-SF-30-9).

\section{References}

[1] R. Radhakrishnan and C. F. Leung, "Load transfer behavior of rock-socketed piles," Journal of Geotechnical Engineering, vol. 115, no. 6, pp. 755-768, 1989.

[2] Z. Y. Lin, Geotechnical Exeperimentaion Manual, China Architecture and Building Press, Beijing, China, 2005, in Chinese.

[3] J. Xu, G. L. Dai, W. M. Gong et al., "A review of research on the shaft resistance of rock-socketed piles," Acta Geotechnica, vol. 1, 2020.

[4] H. B. Seed and L. C. Reese, "The action of soft clay along friction piles," Transactions, vol. 122, pp. 731-754, 1955.

[5] P. Carrubba, "Skin friction on large-diameter piles socketed into rock," Canadian Geotechnical Journal, vol. 34, no. 2, pp. 230-240, 1997.

[6] X. Liu, X. Bai, M. Zhang et al., "Load-bearing characteristics of large-diameter rock-socketed piles based on ultimate load tests," Advances in Materials Science and Engineering, vol. 2020, no. 2, Article ID 6075607, 2020.

[7] J. W. Barrett and L. J. Prendergast, "Empirical shaft resistance of driven piles penetrating weak rock," Rock Mechanics and Rock Engineering, vol. 2020, no. 2, 2020.

[8] Y. Lei, J.-f. Yin, Q.-n. Chen, and Y.-x. Liu, "Experimental study on the rock-socketed segment of pile and analysis of its load-bearing characteristics," Journal of Highway and Transportation Research and Development (English Edition), vol. 11, no. 3, pp. 54-61, 2017.

[9] W. Jonhston, T. S. K. Lam, and A. F. Williams, "Constant normal stiffness direct shear testing for socketed pile design in weak rock," Geotechnique, vol. 37, no. 1, pp. 83-89, 1987.

[10] G. Dai, W. M. Gong, R. Salgado, W. Gong, and M. Zhu, "The effect of sidewall roughness on the shaft resistance of rocksocketed piles," Acta Geotechnica, vol. 12, no. 2, pp. 429-440, 2017.

[11] H.-1. Kou, W. Guo, M.-y. Zhang, and Y.-q. Xu, "Axial resistance of long rock-socketed bored piles in stratified soils," Ocean Engineering, vol. 114, pp. 58-65, 2016.

[12] H. Xing, F. Xiong, and L. Y. Wang, "Research on shaft resistance of rock-socketed piles based on the cavity expansion theory," Marine Georesources \& Geotechnology, vol. 35, no. 6, pp. 873-877, 2017.

[13] C. Luo, G. Cui, L. Deng, H. Zhou, J. Lu, and F. Dai, "Laboratory investigation on shear behaviors of bolt-grout interface subjected to constant normal stiffness," Rock Mechanics and Rock Engineering, vol. 53, no. 3, pp. 1333-1347, 2020.

[14] P. J. N. Pells, R. K. Rowe, and R. M. Turner, "An experimental investigation into side shear for socketed piles in sandstone," in Proceedings of international conference on structural foundations on rock, pp. 291-302, Sydney, Australia, May 1980.

[15] R. K. Rowe and H. H. Armitage, "A design method for drilled piers in soft rock," Canadian Geotechnical Journal, vol. 24, no. 1, pp. 126-142, 1987.

[16] R. G. Horrath, T. C. Kenney, and P. Kozicki, "Methods of improving the performance of drilled piers in weak rock," Canadian Geotechnical Journal, vol. 20, no. 4, pp. 758-772, 1983.

[17] E. Momeni, R. Nazir, D. Jahed Armaghani, and H. Maizir, "Prediction of pile bearing capacity using a hybrid genetic algorithm-based ANN,” Measurement, vol. 57, pp. 122-131, 2014.

[18] H. Xing, J. Wu, and Y. Luo, "Field tests of large-diameter rocksocketed bored piles based on the self-balanced method and their resulting load bearing characteristics," European Journal of Environmental and Civil Engineering, vol. 23, no. 12, pp. 1535-1549, 2019.

[19] J. D. Armaghani, "Developing a hybrid PSO-ANN model for estimating the ultimate bearing capacity of rock-socketed piles," Neural Computing and Applications, vol. 28, no. 2, pp. 391-405, 2017.

[20] E. C. Leong and M. F. Randolph, "Finite element modelling of rock-socketed piles," International Journal for Numerical and Analytical Methods in Geomechanics, vol. 18, no. 1, pp. 25-47, 1994.

[21] A. M. Alnuaim, W. M. Hamid, and A. O. Alshenawy, "Numerical study of skin friction behavior of piles in limestone rock," Soil Mechanics and Foundation Engineering, vol. 57 , no. 3, pp. 265-269.

[22] H. Seol, S. Jeong, and Y. Kim, "Load transfer analysis of rocksocketed drilled shafts by coupled soil resistance," Computers and Geotechnics, vol. 36, no. 3, pp. 446-453, 2009.

[23] J. Yu, Y.-y. Cai, and W.-b. Wu, "Effect of sediment on vertical dynamic impedance of rock-socketed pile with large diameter," Journal of Central South University, vol. 20, no. 10, pp. 2856-2862, 2013.

[24] X. L. Zhang, B. C. Duan, C. Z. Wang et al., "Dynamic response analysis of lateral impact force of frame wharf with rocksocketed piles in inland river steel sheath," Advances in Civil Engineering, vol. 2019, no. 1, p. 6918376, 2019.

[25] B. G. S. T. Gamage, B. Kiriparan, B. Waduge et al., "Piled raft foundation system for tall buildings," ICSECM, vol. 2019, no. 94, 2019.

[26] Ministry of Housing and Urban-Rural Development of People's Republic of China, Technical Code for Building Pile Foundations: JGJ94-2008, China Architecture \& Building Press, Beijing, China, 2008.

[27] J. X. Hua and J. G. Zheng, Geological Engineering Handbook, China Architecture \& Building Press, Beijing, China, 2017.

[28] B. Chen, J. S. Zhuo, and T. S. Wu, "Finite element analysis on bearing behavior of rock-socketed piles," Chinese Journal of Geotechnical Engineering, vol. 24, no. 1, pp. 51-55, 2002, in Chinese.

[29] J. Zhou, C. Zhou, and Q. Feng, "Analytical model for loadtransfer mechanism of rock-socketed drilled piles: considering bond strength of the concrete-rock interface," International Journal of Geomechanics, vol. 20, no. 6, Article ID 04020059, 2020.

[30] S. M. He and G. S. Lu, "Study on load transfer characteristic of rock-socketed pile," Rock and Soil Mechanics, vol. 28, no. 12, pp. 598-2602, 2007, in Chinese.

[31] F. D. Patton, "Multiple modes of shear failure in rock," in Proceedings of the 1st Congress of ISRM, pp. 509-513, Lisboa, Portugal, September 1996. 